Article

\title{
Regeneration of Sodium Hydroxide from a Biogas Upgrading Unit through the Synthesis of Precipitated Calcium Carbonate: An Experimental Influence Study of Reaction Parameters
}

\author{
Francisco M. Baena-Moreno ${ }^{1,2, *}$, Mónica Rodríguez-Galán ${ }^{1}$, Fernando Vega ${ }^{1}$, T. R. Reina ${ }^{2}{ }^{\mathbb{D}}$, \\ Luis F. Vilches ${ }^{1}$ and Benito Navarrete ${ }^{1}$ (D) \\ 1 Chemical and Environmental Engineering Department, Technical School of Engineering, University of \\ Seville, C/Camino de los Descubrimientos s/n, 41092 Sevilla, Spain; mrgmonica@us.es (M.R.-G.); \\ fvega1@us.es (F.V.); luisvilches@us.es (L.F.V.); bnavarrete@us.es (B.N.) \\ 2 Department of Chemical and Process Engineering, University of Surrey, Guildford GU2 7XH, UK; \\ t.ramirezreina@surrey.ac.uk \\ * Correspondence: fbaena2@us.es; Tel.: +34-680-252-606
}

Received: 11 October 2018; Accepted: 22 October 2018; Published: 24 October 2018

\begin{abstract}
This article presents a regeneration method of a sodium hydroxide $(\mathrm{NaOH})$ solution from a biogas upgrading unit through calcium carbonate $\left(\mathrm{CaCO}_{3}\right)$ precipitation as a valuable by-product, as an alternative to the elevated energy consumption employed via the physical regeneration process. The purpose of this work was to study the main parameters that may affect $\mathrm{NaOH}$ regeneration using an aqueous sodium carbonate $\left(\mathrm{Na}_{2} \mathrm{CO}_{3}\right)$ solution and calcium hydroxide $\left(\mathrm{Ca}(\mathrm{OH})_{2}\right)$ as reactive agent for regeneration and carbonate slurry production, in order to outperform the regeneration efficiencies reported in earlier works. Moreover, Raman spectroscopy and Scanning Electron Microscopy (SEM) were employed to characterize the solid obtained. The studied parameters were reaction time, reaction temperature, and molar ratio between $\mathrm{Ca}(\mathrm{OH})_{2}$ and $\mathrm{Na}_{2} \mathrm{CO}_{3}$. In addition, the influence of small quantities of $\mathrm{NaOH}$ at the beginning of the precipitation process was studied. The results indicate that regeneration efficiencies between $53 \%-97 \%$ can be obtained varying the main parameters mentioned above, and also both Raman spectroscopy and SEM images reveal the formation of a carbonate phase in the obtained solid. These results confirmed the technical feasibility of this biogas upgrading process through $\mathrm{CaCO}_{3}$ production.
\end{abstract}

Keywords: carbon capture and utilization; biogas upgrading; calcium carbonate precipitation; chemical absorption

\section{Introduction}

Climate change is one of the major problems that has plagued humanity in recent times, consisting of a significant and lasting modification of local and global patterns of climate on the planet. The frequency and intensity of meteorological phenomena such as rainfall, hurricanes, storms, decreasing extent of ice, rising sea level and, above all, the increasing average temperature of the Earth's atmosphere are the main evidences found by scientists that corroborate climate change $[1,2]$. According to the Intergovernmental Panel on Climate Change (IPCC) [1], the main origin is the anthropogenic emissions of so-called greenhouse gases (GHG), due to the use of fossil fuels such as coal, oil and natural gas for the production of electricity, transportation or industrial uses, $\mathrm{CO}_{2}$ being the most relevant among the greenhouse gases. For this reason, the use of renewables energies which reduce $\mathrm{CO}_{2}$ emissions could be found as one of the fields most investigated in the last decade [3-11]. 
One of the most promising renewable energy sources is biomass [12]. Biomethane is obtained by upgrading biogas produced from anaerobic digestion of different types of biomass. There are several ways to use this biomethane as an energy resource, which depend on technical, economic and legislative factors of each country [13]. Biomethane is an improved biogas from landfills, farms, sewage treatment plants, agriculture or other sources [14]. For use, biomethane must be submitted to a process called upgrading, which separates the undesired compounds (mainly $\mathrm{CO}_{2}$ ) and adapts its composition to the standards set by the legislation corresponding to that suitable for a fuel gas [15]. $\mathrm{CO}_{2}$ content in biogas as produced in anaerobic digestion varies between $35 \%-45 \%[16,17]$. To remove $\mathrm{CO}_{2}$, very diverse techniques have been studied: Pressure Swing Adsorption (PSA) [18,19], Water Scrubbing (WS) [20,21], Organic Physical Scrubbing (OPS) [22,23], Chemical Absorption Scrubbing (CAS) [13,24], Membrane Separation (MS) [25,26] and Cryogenic Separation (CS) [27,28]. CAS is one of the most promising technique [29,30], both with amines (monoethanolamine (MEA) or Piperazine (PZ)) and caustic solvents $(\mathrm{NaOH}$ or potassium hydroxide $(\mathrm{KOH}))$. Previous studies have reported high capture yields and selectivity to $\mathrm{CO}_{2}$, achieving similar capture efficiencies from $90 \%$ to $99 \%$ [31-35]. In the case of amine solvents, a high regeneration efficiency of the solvent can be obtained via physical regeneration, with an acceptable energy consumption [34]. However, compared with the previous solvents explained, when employing caustic solvents, an elevated energy consumption is necessary in order to regenerate the solvent physically, which makes these solvents less usable than the conventional MEA [35]. In this reaction, $\mathrm{Na}_{2} \mathrm{CO}_{3}$ or potassium carbonate $\left(\mathrm{K}_{2} \mathrm{CO}_{3}\right)$ is obtained as a consequence of the absorption step.

$$
2 \mathrm{NaOH} / \mathrm{KOH}(\mathrm{aq})+\mathrm{CO}_{2}(\mathrm{~g}) \rightarrow+\mathrm{Na}_{2} \mathrm{CO}_{3} / \mathrm{K}_{2} \mathrm{CO}_{3}+\mathrm{H}_{2} \mathrm{O}
$$

An alternative path for $\mathrm{CO}_{2}$ utilization that avoids the energy penalty in the regeneration stage of the solvent would be the synthesis and separation of chemicals based on calcium $\left(\mathrm{Ca}^{+}\right)$by the precipitation processes into the solvent solution, as for example in $\mathrm{Ca}(\mathrm{OH})_{2}$ or residues with high $\mathrm{Ca}^{+}$content. This alternative is very attractive from an economic point of view in order to drastically reduce costs of $\mathrm{CO}_{2}$ capture and valorize $\mathrm{CO}_{2}$ as a commercial by-product. An interesting by-product to be taken into account when alkaline hydroxides are used as solvents is $\mathrm{CaCO}_{3} . \mathrm{CaCO}_{3}$ can be produced through chemical reaction with $\mathrm{Ca}(\mathrm{OH})_{2}$ and precipitated as a solid [33], according to the next reaction:

$$
\mathrm{Na}_{2} \mathrm{CO}_{3} / \mathrm{K}_{2} \mathrm{CO}_{3}(\mathrm{aq})+\mathrm{Ca}(\mathrm{OH})_{2}(\mathrm{~s}) \rightarrow 2 \mathrm{NaOH} / \mathrm{KOH}(\mathrm{aq})+\mathrm{CaCO}_{3}(\mathrm{~s})
$$

The type of $\mathrm{CaCO}_{3}$ obtained as a by-product is called Precipitated Calcium Carbonate (PCC). PCC is consumed in huge quantities and in variated applications for different industrial sectors, such as a filler for plastic materials, paper, foods, printing ink and medical necessities [36]. This synergy process between biogas upgrading, $\mathrm{CO}_{2}$ capture and PCC production is shown in Figure 1.

This process is much less energy intensive than physical regeneration previously studied by various authors $[35,37,38]$, making the process economically attractive. Many researches focused on the carbonation of residues for storing $\mathrm{CO}_{2}$, as for instance steel slags [39], air pollution control residues [32,33], argon oxygen decarburization slags [23], incineration bottom ash [40] or basic oxygen furnace slags [41]. Baciocchi et al. [32,33] proposed an application of the process above explained using both $\mathrm{NaOH}$ and $\mathrm{KOH}$ as solvents, and Air Pollution Control residues as $\mathrm{Ca}^{+}$sources, focusing on the amount of $\mathrm{CO}_{2}$ that could be definitely stored by this residues [32,42]. However, their results showed a non-valuable by-product from a commercial point of view and solvent regeneration efficiencies from $50 \%$ to $60 \%$ due to the employment of the residues. Therefore, the purpose of this work was to study the main parameters that may affect $\mathrm{NaOH}$ regeneration using an aqueous $\mathrm{Na}_{2} \mathrm{CO}_{3}$ solution and $\mathrm{Ca}(\mathrm{OH})_{2}$ as a reactive for regeneration and carbonate slurry production, in order to achieve better regeneration efficiencies than previous works and obtaining PCC as a valuable by-product. With this, 
the foundations for future works are laid, in which valuable by-products would be obtained that would allow to achieve a more economical and sustainable process for carbon capture and utilization.

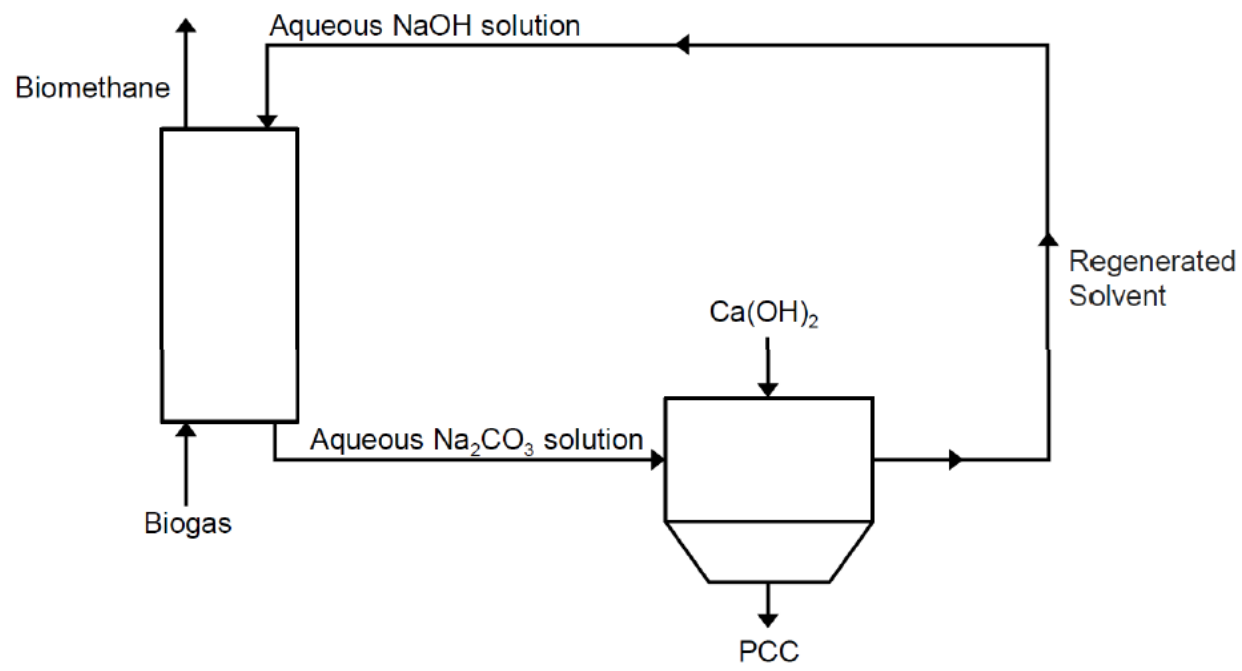

Figure 1. Biogas upgrading through Precipitated Calcium Carbonate (PCC) production.

\section{Materials and Methods}

\subsection{Materials}

Chemical compounds used in the experiments $\left(\mathrm{Ca}(\mathrm{OH})_{2}, \mathrm{Na}_{2} \mathrm{CO}_{3}, \mathrm{CaCO}_{3}, \mathrm{NaOH}\right)$ were provided by PanReac-AppliChem (Barcelona, Spain) (pure-grade or pharma-grade, 99\% purity).

\subsection{Regeneration Experiments}

In general, the regeneration experiments were carried out following the methodology exposed below, which will be explained in greater depth later. First, the solutions of the reactants were prepared, at the same time that the instruments needed for the precipitation reaction were tuned. After these steps, the reaction was produced, which, once finished, was filtered and separated quickly for analyzing. The main parameters considered for results were $\mathrm{NaOH}$ regeneration efficiency and carbonate phase reached. The three most important variables studied in these experiments were the reaction time, the reaction temperature and the molar ratio between $\mathrm{Ca}(\mathrm{OH})_{2}$ and $\mathrm{Na}_{2} \mathrm{CO}_{3}$, which according to previous works may have a considerable effect on the regeneration efficiency of the process [32,33]. The matrix of experiments carried out can be found in Table 1. In order to study how each parameter affects by itself, a standard value was set for each of them, according to the bibliography for similar studies [31-33,35], and later they were varied one by one. The standard value for temperature reaction was set at $50{ }^{\circ} \mathrm{C}$, molar ratio at $1.2 \mathrm{~mol} \mathrm{Ca} / \mathrm{Na}_{2} \mathrm{CO}_{3}$ and reaction time at $30 \mathrm{~min}$. Furthermore, the influence of an initial addition of $\mathrm{NaOH}$ in the $\mathrm{Na}_{2} \mathrm{CO}_{3}$ solution was tested, in order to analyze the effect on $\mathrm{NaOH}$ regeneration.

Lab scale batch precipitation experiments were carried out in a $600 \mathrm{~mL}$ beaker placed in a water bath to control temperature tests. The value of the $\mathrm{pH}$ gives some clues of the compounds that may be present in the solution. Therefore, to check that the $\mathrm{NaOH}$ regeneration reaction had the desired effect, the $\mathrm{pH}$ was measured and checked to be in the range 12-14, which is characteristic for hydroxides solutions [31]. During each whole experiment time, the solutions were stirred by an electromagnetic magnet at a constant speed of $1000 \mathrm{rpm}$. For temperature and $\mathrm{pH}$ measuremsent, a thermometer and a pH-meter by Trison Instrument (BANDELIN electronic GmbH \& Co. KG, Berlin, Germany) were employed. Measures were continually carried out and recorded in a data logger. Reproducibility checks were conducted resulting in an overall experimental error of $\pm 2 \%$ for the regeneration efficiency calculations. The first steps of the procedures followed were to prepare both 
$\mathrm{Na}_{2} \mathrm{CO}_{3}$ and $\mathrm{Ca}(\mathrm{OH})_{2}$ solutions. In the case of $\mathrm{Na}_{2} \mathrm{CO}_{3}$, the aqueous solution was set at $20 \mathrm{~g} / 100 \mathrm{~mL}$ according to the basis typical values expected after the absorption step [21,28], while the concentration of the $\mathrm{Ca}(\mathrm{OH})_{2}$ solution was stoichiometrically calculated for each test, as will be explained later. At the beginning of each experiment, a $200 \mathrm{~mL}$ distilled water slurry of $\mathrm{Ca}(\mathrm{OH})_{2}$ was poured into the beaker placed. After $15 \mathrm{~min}, 200 \mathrm{~mL}$ of $\mathrm{Na}_{2} \mathrm{CO}_{3}$ aqueous solution was added to start the reaction time. At the end of each experiment, the solution was vacuum filtered immediately and $50 \mathrm{~mL}$ sample was taken to determine the concentration of $\mathrm{NaOH}$ by inductively coupled plasma atomic emission spectroscopy. The solid obtained by filtration was dried at $105^{\circ} \mathrm{C}$ to ensure a carbonate phase which was characterized by means of Scanning Electron Microscopy (SEM) and Raman spectroscopy.

Table 1. Matrix of the experiments carried out.

\begin{tabular}{|c|c|c|c|c|}
\hline TEST & TIME (MIN) & TEMPERATURE $\left({ }^{\circ} \mathrm{C}\right)$ & MOLAR RATIO & NaOH INITIAL (M) \\
\hline Standard & 30 & 50 & 1.2 & 0 \\
\hline 1 & 5 & 50 & 1.2 & 0 \\
\hline 2 & 15 & 50 & 1.2 & 0 \\
\hline 3 & 45 & 50 & 1.2 & 0 \\
\hline 4 & 60 & 50 & 1.2 & 0 \\
\hline 5 & 90 & 50 & 1.2 & 0 \\
\hline 6 & 120 & 50 & 1.2 & 0 \\
\hline 7 & 30 & 30 & 1.2 & 0 \\
\hline 8 & 30 & 35 & 1.2 & 0 \\
\hline 9 & 30 & 40 & 1.2 & 0 \\
\hline 10 & 30 & 45 & 1.2 & 0 \\
\hline 11 & 30 & 50 & 1.2 & 0 \\
\hline 12 & 30 & 55 & 1.2 & 0 \\
\hline 13 & 30 & 60 & 1.2 & 0 \\
\hline 14 & 30 & 65 & 1.2 & 0 \\
\hline 15 & 30 & 70 & 1.2 & 0 \\
\hline 16 & 30 & 50 & 0.7 & 0 \\
\hline 17 & 30 & 50 & 0.8 & 0 \\
\hline 18 & 30 & 50 & 0.9 & 0 \\
\hline 19 & 30 & 50 & 1 & 0 \\
\hline 20 & 30 & 50 & 1.1 & 0 \\
\hline 21 & 30 & 50 & 1.2 & 0 \\
\hline 22 & 30 & 50 & 1.3 & 0 \\
\hline 23 & 30 & 50 & 1.4 & 0 \\
\hline 24 & 30 & 50 & 1.5 & 0 \\
\hline 25 & 5 & 50 & 1.2 & 1 \\
\hline 26 & 15 & 50 & 1.2 & 1 \\
\hline 27 & 30 & 50 & 1.2 & 1 \\
\hline 28 & 45 & 50 & 1.2 & 1 \\
\hline 29 & 60 & 50 & 1.2 & 1 \\
\hline 30 & 90 & 50 & 1.2 & 1 \\
\hline 31 & 120 & 50 & 1.2 & 1 \\
\hline
\end{tabular}

Raman measurements of the powders samples were recorded using a Thermo DXR2 spectrometer (Thermo Fisher Scientific, Waltham, MA, USA) equipped with a Leica DMLM microscope (Thermo Fisher Scientific, Waltham, MA, USA). The wavelength of applied excitation line was $532 \mathrm{~nm}$ ion laser and $50 \times$ objective of 8 -mm optical was used to focus the depolarized laser beam on a sport of about $3 \mu \mathrm{m}$ in diameter.

A JEOL JSM6400 (JEOL Ltd., Tokyo, Japan) operated at $20 \mathrm{KV}$ equipped with energy dispersive X-ray spectroscopy (EDX) and a wavelength dispersive X-ray spectroscopy (WDS) systems was used for the microstructural/chemical characterization (SEM with EDS and WDS). 


\section{Results}

This section reports the experimental results of the different tests carried out. The results of $\mathrm{NaOH}$ regeneration efficiency are presented, with reference to every parameter studied. $\mathrm{NaOH}$ regeneration efficiency is defined has follow:

$$
\mathrm{NaOH} \text { regeneration efficiency }(\%)=\frac{\mathrm{NaOH} \text { regenerated }}{\text { Maximum } \mathrm{NaOH} \text { to regenerate }} \times 100
$$

As it has been set previously, $\mathrm{NaOH}$ regenerated was determined by inductively coupled plasma atomic emission spectroscopy, while the maximum $\mathrm{NaOH}$ to be regenerated can be easily stochiometrically calculated from the concentration of the $\mathrm{Na}_{2} \mathrm{CO}_{3}$ initial solution.

Then, some Raman spectroscopies of PCC are shown to demonstrate the carbonate phase reached, which are accompanied by some SEM images that contribute to verify the results predicted by Raman.

\section{1. $\mathrm{NaOH}$ Regeneration}

Figures $2-4$ show the regeneration efficiency curves of the filtered solutions resulting from regeneration experiments carried out with $\mathrm{Ca}(\mathrm{OH})_{2}$ at different reaction times, temperatures and molar ratios, respectively.

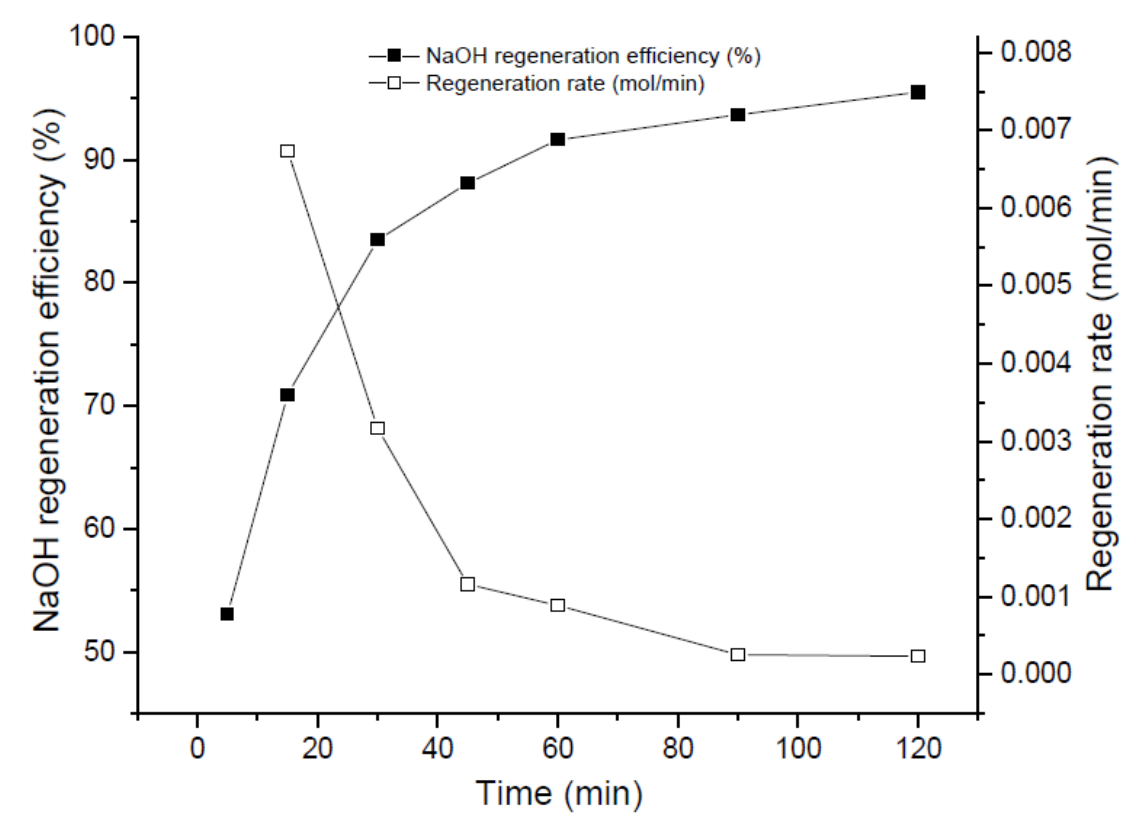

Figure 2. Evolution of $\mathrm{NaOH}$ regeneration with time at fixed Temperature $50{ }^{\circ} \mathrm{C}$ and $\mathrm{R}=1.2$.

\subsubsection{Reaction Time Effect}

Figure 2 shows the effect of the reaction time in the regeneration phenomenon. As depicted in the plot, $\mathrm{NaOH}$ regeneration efficiency varies from $53 \%$ to $83 \%$ approximately from $5 \mathrm{~min}$ to $30 \mathrm{~min}$ of reaction time, and later, the slope of the curve changes drastically, passing through $91 \%$ regeneration efficiency at $60 \mathrm{~min}$, until achieving a $95 \%$ of $\mathrm{NaOH}$ regeneration at $120 \mathrm{~min}$. This means, in fact, that in a hypothetical real reactor, a duplication of its volume will be necessary to achieve an increase of $4 \%$ approximately (from $30 \mathrm{~min}$ to $60 \mathrm{~min}$ ). As can be seen, from $60 \mathrm{~min}$ to $120 \mathrm{~min}$, less than $0.001 \mathrm{~mol}$ $\mathrm{NaOH}$ is regenerated per minute. Thus, to operate at $120 \mathrm{~min}$ residence time is not worthy from a plant design point of view. The intersection of the two curves (regeneration rate and regeneration efficiency) indicates an interesting and very likely optimum operational point where a fair balance between both tendencies can be reached. 


\subsubsection{Temperature Influence}

As for the temperature influence, Figure 3 shows the effect of different temperatures in the regeneration studies. Temperature effect reflects a linear trend showcasing a direct correlation between $\mathrm{NaOH}$ regeneration efficiency and process temperature. Indeed, in the best case scenario $\left(\right.$ at $\left.70{ }^{\circ} \mathrm{C}\right)$ it can reach $97 \%$ of $\mathrm{NaOH}$ regeneration efficiency. Normalizing the regeneration capacity by the incremental temperature (empty symbols in the Figure) maximum is obtained at around $50{ }^{\circ} \mathrm{C}$ which somehow indicates that the increment in temperature has a stronger impact on the regeneration efficiency in the low-medium temperature range. This is an important result to be highlighted from an energy consumption perspective, as a temperature of $50{ }^{\circ} \mathrm{C}$ could be easily achieved through low-cost and/or renewable energy sources such as solar.

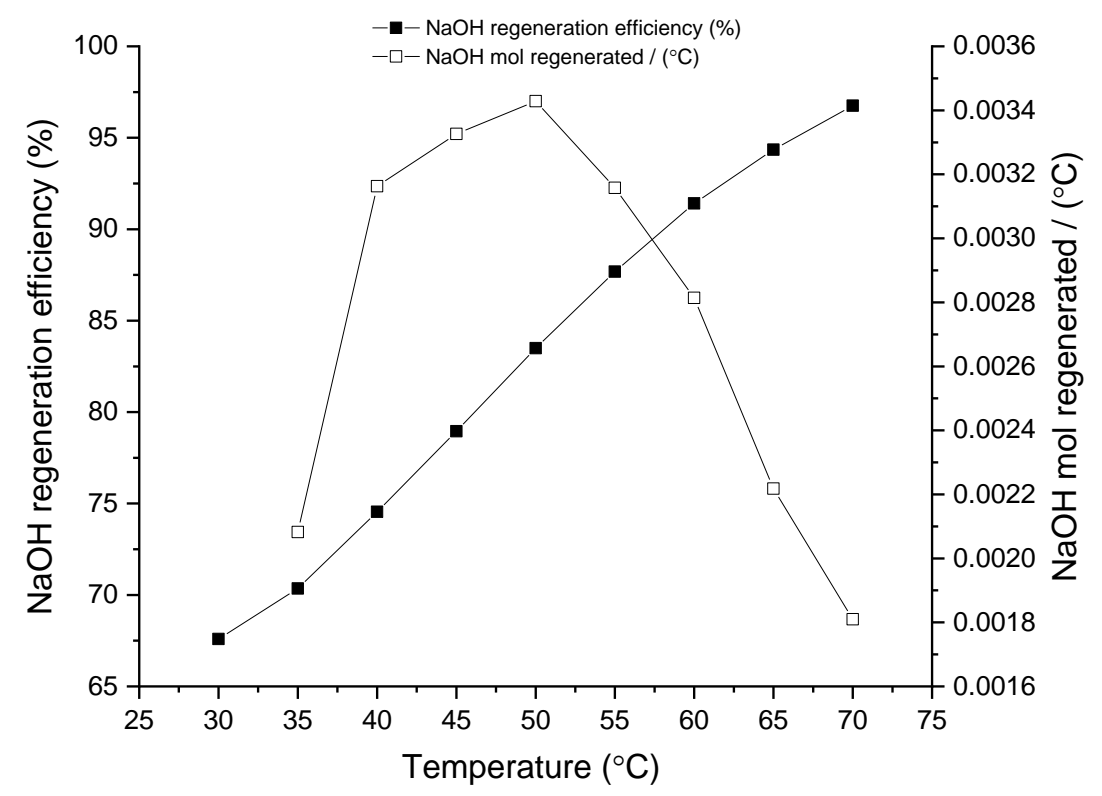

Figure 3. Influence of temperature on $\mathrm{NaOH}$ regeneration. Experiments carried out at $\mathrm{R}=1.2$ and $\mathrm{t}=30 \mathrm{~min}$.

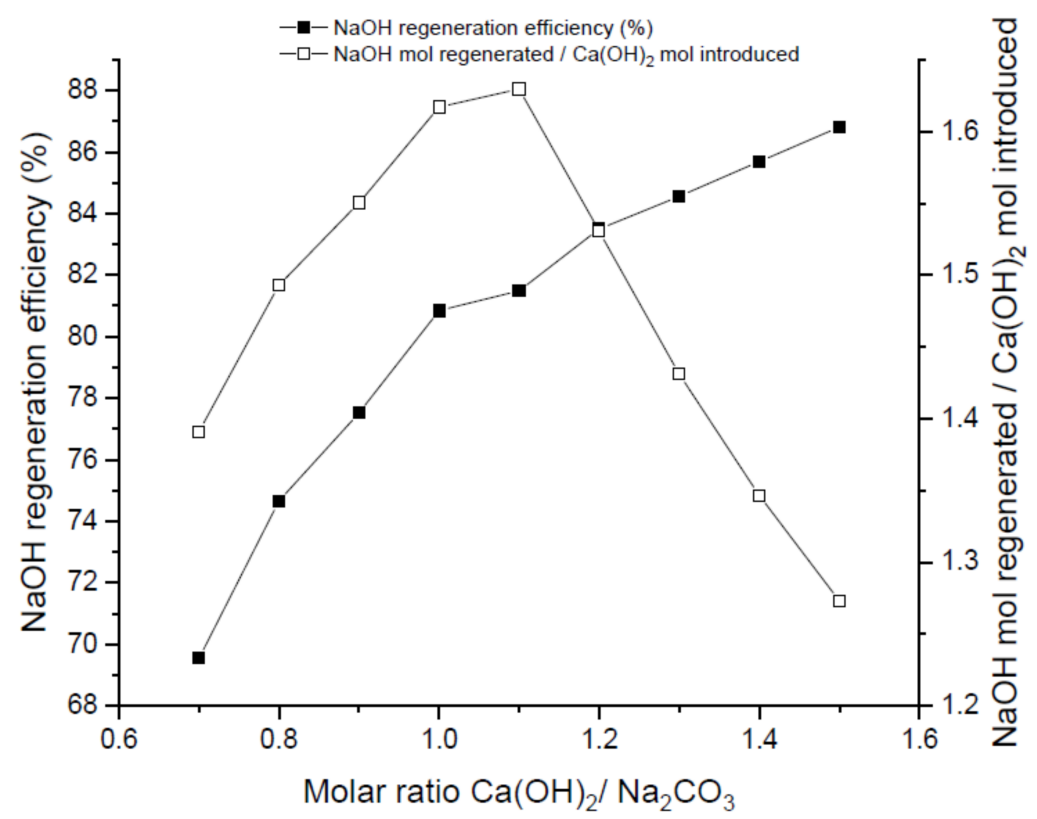

Figure 4. Influence of molar ratio $(\mathrm{R})$ in the regeneration experiments. Runs conducted at $\mathrm{t}=30 \mathrm{~min}$ and $50{ }^{\circ} \mathrm{C}$. 


\subsubsection{Molar Ratio Influence}

Molar ratio inlet carbonate/precipitant agent is another important parameter to consider in the regeneration process. As can be seen in Figure 4, $\mathrm{NaOH}$ regeneration efficiency is favored by an increase of the molar ratio. Nevertheless, this increase of molar ratio promotes a higher quantity of $\mathrm{Ca}^{2+}$ ions that should be removed before recirculating the absorbent to the absorption tower in order to prevent accumulation of $\mathrm{Ca}(\mathrm{OH})_{2}$ which eventually may lead to fouling phenomenon in the tower. In parallel, as can be observed in Figure $4, \mathrm{NaOH}$ mol regeneration per mol of $\mathrm{Ca}(\mathrm{OH})_{2}$ introduced decreases upon increasing the molar ratio above a threshold value of $R=1.1$. This value set an optimum operational point beyond which no further benefits are envisaged from the process point of view.

\subsubsection{Effect of $\mathrm{NaOH}$ Spark in the Regeneration Efficiency}

The addition of small quantities of $\mathrm{NaOH}$ at the beginning of the precipitation process may promote the recovery of $\mathrm{NaOH}$ (initially entering the precipitation reactor in the form of $\mathrm{Na}_{2} \mathrm{CO}_{3}$ ). Also, it should be taken into account that, in a real industrial plant, $100 \%$ conversion from $\mathrm{NaOH}$ to $\mathrm{Na}_{2} \mathrm{CO}_{3}$ would hardly be reached in the absorption stage. In this sense, small amounts of $\mathrm{NaOH}$ as "sparking species" were added to investigate its effect on the process. The impact exerted by the addition of an initial concentration of $\mathrm{NaOH}(1 \mathrm{M})$ in the $\mathrm{Na}_{2} \mathrm{CO}_{3}$ solution in terms of $\mathrm{NaOH}$ regeneration efficiency is reported in Figure 5. Analyzing this Figure, it may be noted that the $\mathrm{NaOH}$ regeneration was slower than the results obtained without an initial $\mathrm{NaOH}$ concentration. It seems that the presence of alkaline compounds do not benefit the regeneration process-a fact that can be related to the poorer solubility of $\mathrm{Ca}(\mathrm{OH})_{2}$ due to the ion common effect as previously observed elsewhere $[32,36,43]$.

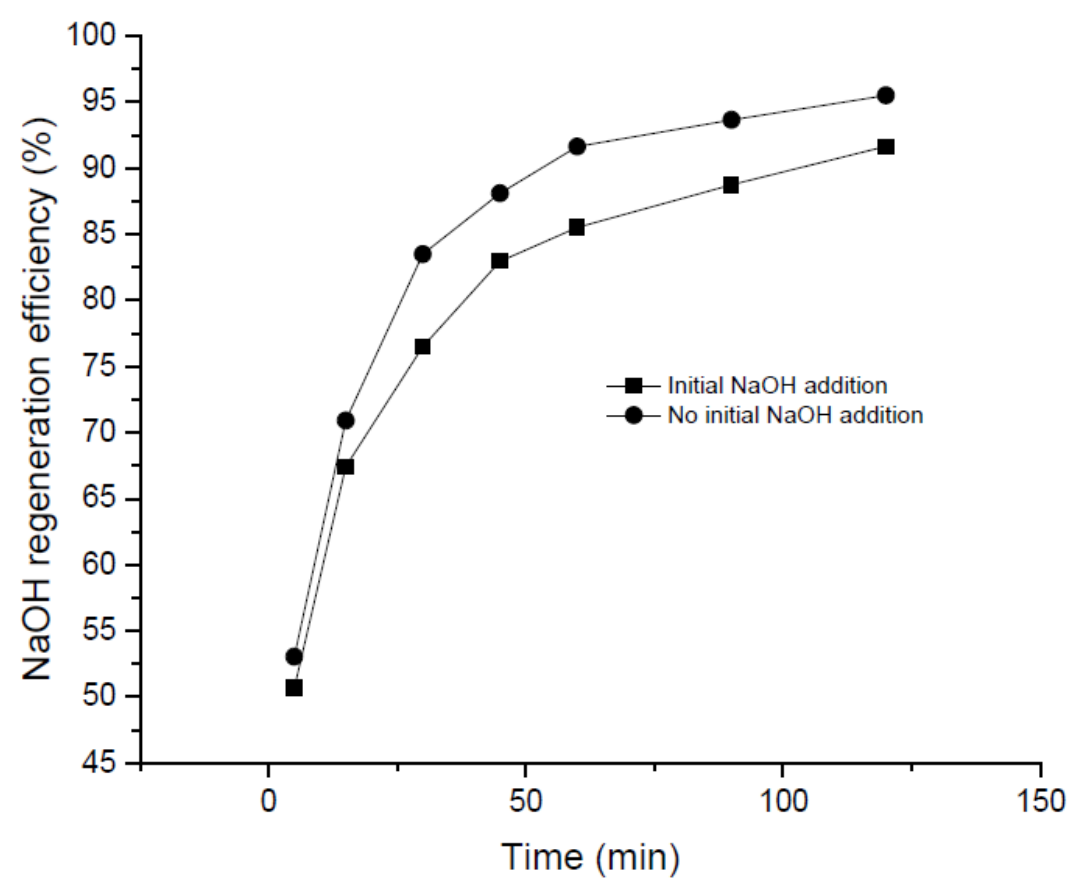

Figure 5. Comparison curves of $\mathrm{NaOH}$ regeneration efficiency with and without initial addition of $\mathrm{NaOH}$.

\subsection{Physicochemical Characterization of the PCC}

Aiming to determine the purity of the carbonates obtained during the recovery process, a combined Raman-SEM study was conducted on selected samples. Figure 6 shows the Raman spectra of the recovered carbonated after $30 \mathrm{~min}$ of reaction at $50{ }^{\circ} \mathrm{C}$ using a $\mathrm{R}=1.2$ in comparison with 
standards samples of pure $\mathrm{CaCO}_{3}$ and pure $\mathrm{Ca}(\mathrm{OH})_{2} \cdot \mathrm{CaCO}_{3}$ typically presents a monoclinic structure belonging to the $\mathrm{P} 21 / \mathrm{c}$ group [44]. The main characteristic band of $\mathrm{CaCO}_{3}$ polymorphs is a strong and narrow feature which appears at around $1100 \mathrm{~cm}^{-1}$. Also, another band ca. $700 \mathrm{~cm}^{-1}$ is typically ascribed to this type of structure [44]. As can be seen, these two peaks are presented in PCC spectra, confirming the successful precipitation process. In fact, the spectrum of our PCC sample resembles that of the $\mathrm{CaCO}_{3}$ standard as shown in Figure 6. Nevertheless, it must be highlighted that a certain amount of $\mathrm{Ca}(\mathrm{OH})_{2}$ remains present in our solid sample as intended by the Raman vibration mode at ca. $400 \mathrm{~cm}^{-1}$ which matches well with the most intense band on the $\mathrm{Ca}(\mathrm{OH})_{2}$ standard. In fact, these data correlate well with the regeneration efficiency data discussed above where $100 \%$ regeneration is never reached. In this sense, Raman experiments indicate that despite the fact that the regeneration process is highly effective, there is still some room for further improvements.

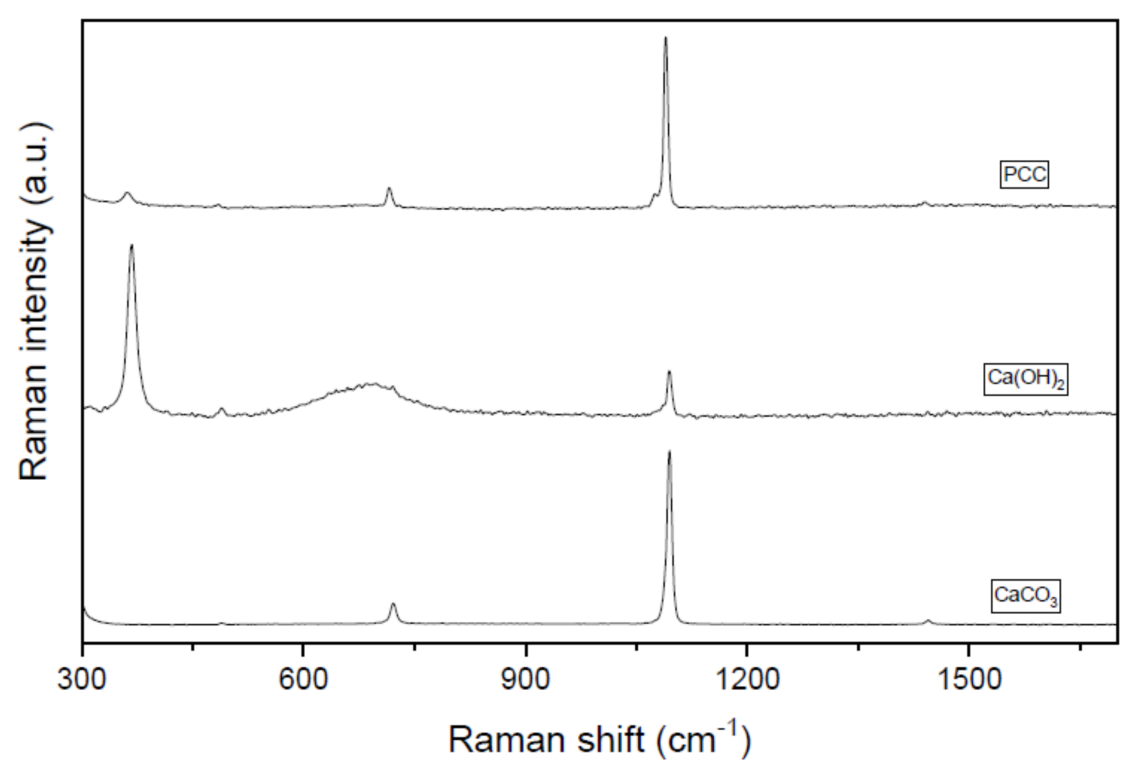

Figure 6. Raman spectra of the PCC obtained (time $=30 \mathrm{~min}, \mathrm{~T}=50{ }^{\circ} \mathrm{C}, \mathrm{R}=1.2$ ) and the $\mathrm{Ca}(\mathrm{OH})_{2}$ and $\mathrm{CaCO}_{3}$ standards.

Scanning Electron Microscopy images are useful to gain further insights on the samples structures. Selected SEM images of different sections of the sample studied by Raman are presented in Figure 7 . SEM images again confirmed the presence of $\mathrm{CaCO}_{3}$ with the typical morphology of calcite as previously observed by Altiner et al. [45]. In the case of SEM, it is hard to distinguish between $\mathrm{CaCO}_{3}$ and $\mathrm{Ca}(\mathrm{OH})_{2}$ - especially when the amount of $\mathrm{Ca}(\mathrm{OH})_{2}$ is just a minor contribution in the overall sample composition. In general terms, our SEM study confirms that the successful carbonate precipitation is in good agreement with the regeneration efficiency studies and the Raman results. 

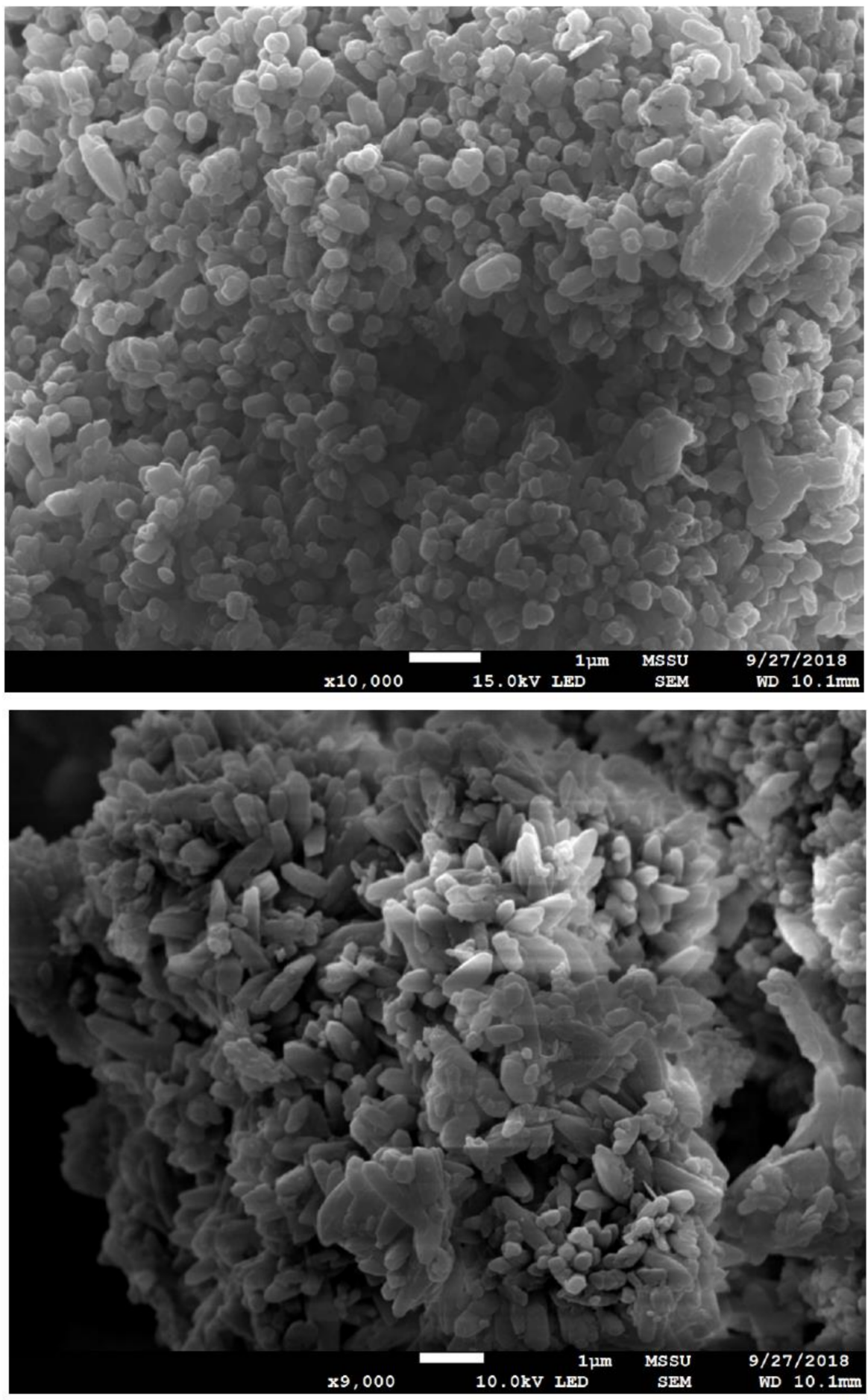

Figure 7. SEM images of the PCC obtained (time $=30 \mathrm{~min}, \mathrm{~T}=50^{\circ} \mathrm{C}, \mathrm{R}=1.2$ ).

\section{Conclusions}

The results obtained from this lab scale work have confirmed the technical feasibility of this biogas upgrading process through PCC production. In general, the majority of the tests have shown better regeneration efficiencies than previous studies identified in the first section of this work (53\%-97\% vs. 50\%-60\%) [32,33]. The multiple reaction parameters have a different impact on the overall process performance. For instance, it was identified that the ideal reaction time would be around $30-60 \mathrm{~min}$ for $\mathrm{T}=50^{\circ} \mathrm{C}$ and $\mathrm{R}=1.2$, leading to compact reactor units. As for the temperature 
effect, a maximum $\mathrm{NaOH}$ mol regenerated per grade is reached at $50{ }^{\circ} \mathrm{C}$ for $\mathrm{t}=30 \mathrm{~min}$ and $\mathrm{R}=1.2$; this would be an advisable value for a real process since it could be reached easily through the employment of a renewable energy source. The molar ratio $\mathrm{Ca}(\mathrm{OH})_{2} / \mathrm{Na}_{2} \mathrm{CO}_{3}$ also influences the process, 1.1 being an ideal ratio to be implemented for realistic operations, for $\mathrm{t}=30 \mathrm{~min}$ and $\mathrm{T}=50^{\circ} \mathrm{C}$. This result has been chosen taking into account the maximum in the curve of $\mathrm{NaOH}$ mol regeneration per mol of $\mathrm{Ca}(\mathrm{OH})_{2}$. The presence of small quantities of $\mathrm{NaOH}$ do not benefit the regeneration process and in fact it produces a decrease in the regeneration efficiency due to the ion common effect; this would suggest an effort to get the maximum percentage of $\mathrm{NaOH}$ conversion to $\mathrm{Na}_{2} \mathrm{CO}_{3}$ in the absorption stage.

Raman and SEM studies confirm the large majority presence of $\mathrm{CaCO}_{3}$ on the recovered material. Interestingly, although the obtained solid is mainly composed by calcite type $\mathrm{CaCO}_{3}$, some traces of $\mathrm{Ca}(\mathrm{OH})_{2}$ are still present. This opens some room for further research to improve the regeneration process.

Author Contributions: Conceptualization, F.M.B.-M., L.F.V. and B.N.; Methodology, F.M.B.-M., M.R.-G., F.V. and T.R.R.; Data curation, F.M.B.-M. and T.R.R.; Writing-original draft preparation, F.M.B.-M., T.R.R., M.R.-G., B.N.; Writing一review and editing, F.M.B.-M., T.R.R., M.R.-G., B.N.; Supervision, T.R.R., M.R.-G., B.N.; Funding acquisition, B.N., L.F.V. and T.R.R.

Funding: This work was supported by University of Seville through its V PPIT-US. Financial support for this work was also provided by the EPSRC grant EP/R512904/1 as well as the Royal Society Research Grant RSGR1180353. This work was also partially sponsored by the CO2Chem UK through the EPSRC grant EP/P026435/1.

Conflicts of Interest: The authors declare no conflict of interest.

\section{References}

1. IPCC. Global Warming of $1.5^{\circ} \mathrm{C}$. Summary for Policymakers; Intergovernamental Panel on Climate Change: Incheon, Korea, 2018.

2. International Energy Agency. World Energy Outlook Special Report: Energy and Climate Change; International Energy Agency: Paris, France, 2015.

3. Decardi-Nelson, B.; Liu, S.; Liu, J. Improving Flexibility and Energy Efficiency of Post-Combustion $\mathrm{CO}_{2}$ Capture Plants Using Economic Model Predictive Control. Processes 2018, 6, 135. [CrossRef]

4. Tollkötter, A.; Kockmann, N. Absorption and Chemisorption of Small Levitated Single Bubbles in Aqueous Solutions. Processes 2014, 2, 200-215. [CrossRef]

5. Adams, T.A.; Hoseinzade, L.; Madabhushi, P.B.; Okeke, I.J. Comparison of $\mathrm{CO}_{2}$ Capture Approaches for Fossil-Based Power Generation: Review and Meta-Study. Processes 2017, 5, 44. [CrossRef]

6. Taimoor, A.A.; Al-shahrani, S.; Muhammad, A. Ionic Liquid (1-Butyl-3-Metylimidazolium Methane Sulphonate) Corrosion and Energy Analysis for High Pressure $\mathrm{CO}_{2}$ Absorption Process. Processes 2018, 5, 45. [CrossRef]

7. Li, J.; Ahmed, R.; Li, X. Thermodynamic Modeling of $\mathrm{CO}_{2}-\mathrm{N}_{2}-\mathrm{O}_{2}$-Brine-Carbonates in Conditions from Surface to High Temperature and Pressure. Energies 2018, 11, 2627. [CrossRef]

8. Hu, J.; Galvita, V.; Poelman, H.; Marin, G. Advanced Chemical Looping Materials for $\mathrm{CO}_{2}$ Utilization: A Review. Materials 2018, 11, 1187. [CrossRef] [PubMed]

9. Zhang, Z.; Yan, Y.; Zhang, L.; Chen, Y.; Ju, S. CFD investigation of $\mathrm{CO}_{2}$ capture by methyldiethanolamine and 2-(1-piperazinyl)-ethylamine in membranes: Part B. Effect of membrane properties. J. Nat. Gas Sci. Eng. 2014, 19, 311-316. [CrossRef]

10. Zhang, Z.; Cai, J.; Chen, F.; Li, H.; Zhang, W.; Qi, W. Progress in enhancement of $\mathrm{CO}_{2}$ absorption by nanofluids: A mini review of mechanisms and current status. Renew. Energy 2018, 118, 527-535. [CrossRef]

11. Zhang, Z.; Li, H.; Chang, H.; Pan, Z.; Luo, X. Machine learning predictive framework for $\mathrm{CO}_{2}$ thermodynamic properties in solution. J. $\mathrm{CO}_{2}$ Util. 2018, 26, 152-159. [CrossRef]

12. Patel, D.; Kellici, S.; Saha, B. Green Process Engineering as the Key to Future Processes. Processes 2014, 10, 311-332. [CrossRef]

13. Zhang, Z.; Li, Y.; Zhang, W.; Wang, J.; Soltaninan, M.R.; Olabie, A.G. Effectiveness of amino acid salt solutions in capturing $\mathrm{CO}_{2}$ : A review. Renew. Sustain. Energy Rev. 2018, 98, 179-188. [CrossRef]

14. Wheeler, P.; Holm-Nielsen, J.B.; Jaatinen, T.; Wellinger, A.; Lindberg, A.; Pettigrew, A. Biogas Upgrading and Utilisation; IEA Bioenergy: Paris, France, 1999; pp. 3-20. 
15. Petersson, A.; Wellinger, A. Biogas Upgrading Technologies-Developments and Innovations; IEA Bioenergy: Paris, France, 2009; Volume 20. [CrossRef]

16. Zhou, K.; Chaemchuen, S.; Verpoort, F. Alternative materials in technologies for Biogas upgrading via $\mathrm{CO}_{2}$ capture. Renew. Sustain. Energy Rev. 2017, 79, 1414-1441. [CrossRef]

17. Kadam, R.; Panwar, N.L. Recent advancement in biogas enrichment and its applications. Renew. Sustain. Energy Rev. 2017, 73, 892-903. [CrossRef]

18. Alonso-Vicario, A.; Ochoa-Gómez, J.R.; Gil-Río, S.; Gómez-Jiménez-Aberasturi, O.; Ramírez-López, C.A.; Torrecilla-Soria, J.; Domínguez, A. Purification and upgrading of biogas by pressure swing adsorption on synthetic and natural zeolites. Microporous Mesoporous Mater. 2010, 134, 100-107. [CrossRef]

19. Kim, Y.J.; Nam, Y.S.; Kang, Y.T. Study on a numerical model and PSA (pressure swing adsorption) process experiment for $\mathrm{CH}_{4} / \mathrm{CO}_{2}$ separation from biogas. Energy 2015, 91, 732-741. [CrossRef]

20. Nie, H.; Jiang, H.; Chong, D.; Wu, Q.; Xu, C.; Zhou, H. Comparison of water scrubbing and propylene carbonate absorption for biogas upgrading process. Energy Fuels 2013, 27, 3239-3245. [CrossRef]

21. Budzianowski, W.M.; Wylock, C.E.; Marciniak, P.A. Power requirements of biogas upgrading by water scrubbing and biomethane compression: Comparative analysis of various plant configurations. Energy Convers. Manag. 2017, 141, 2-19. [CrossRef]

22. Niesner, J.; Jecha, D.; Stehlík, P. Biogas upgrading technologies: State of art review in European region. Chem. Eng. Trans. 2013, 35, 517-522. [CrossRef]

23. Ozturk, B.; Demirciyeva, F. Comparison of biogas upgrading performances of different mixed matrix membranes. Chem. Eng. J. 2013, 222, 209-217. [CrossRef]

24. Cousins, A.; Wardhaugh, L.T.; Feron, P.H.M. A survey of process flow sheet modifications for energy efficient $\mathrm{CO}_{2}$ capture from flue gases using chemical absorption. Int. J. Greenh. Gas Control Int. J. 2011, 5, 605-619. [CrossRef]

25. Chen, X.Y.; Vinh-Thang, H.; Ramirez, A.A.; Rodrigue, D.; Kaliaguine, S. Membrane gas separation technologies for biogas upgrading. RSC Adv. 2015, 5, 24399-24448. [CrossRef]

26. Zhang, Z.; Yan, Y.; Zhang, L.; Chen, Y.; Ran, J.; Pu, G.; Qin, C. Theoretical Study on $\mathrm{CO}_{2}$ Absorption from Biogas by Membrane Contactors: Effect of Operating Parameters. Ind. Eng. Chem. Res. 2014, 53, 14075-14083. [CrossRef]

27. Tuinier, M.J.; Van Sint Annaland, M. Biogas purification using cryogenic packed-bed technology. Ind. Eng. Chem. Res. 2012, 51. [CrossRef]

28. Chiesa, P.; Campanari, S.; Manzolini, G. $\mathrm{CO}_{2}$ cryogenic separation from combined cycles integrated with molten carbonate fuel cells. Int. J. Hydrogen Energy 2011, 36, 10355-10365. [CrossRef]

29. Ryckebosch, E.; Drouillon, M.; Vervaeren, H. Techniques for transformation of biogas to biomethane. Biomass Bioenergy 2011, 35, 1633-1645. [CrossRef]

30. Tippayawong, N.; Thanompongchart, P. Biogas quality upgrade by simultaneous removal of $\mathrm{CO}_{2}$ and $\mathrm{H}_{2} \mathrm{~S}$ in a packed column reactor. Energy 2010, 35, 4531-4535. [CrossRef]

31. Baciocchi, R.; Costa, G.; Gavasci, R.; Lombardi, L.; Zingaretti, D. Regeneration of a spent alkaline solution from a biogas upgrading unit by carbonation of APC residues. Chem. Eng. J. 2012, 179, 63-71. [CrossRef]

32. Baciocchi, R.; Corti, A.; Costa, G.; Lombardi, L.; Zingaretti, D. Storage of carbon dioxide captured in a pilot-scale biogas upgrading plant by accelerated carbonation of industrial residues. Energy Procedia 2011, 4, 4985-4992. [CrossRef]

33. Baciocchi, R.; Carnevale, E.; Costa, G.; Gavasci, R.; Lombardi, L.; Olivieri, T.; Zanchi, L.; Zingaretti, D. Performance of a biogas upgrading process based on alkali absorption with regeneration using air pollution control residues. Waste Manag. 2013, 33, 2694-2705. [CrossRef] [PubMed]

34. Vega, F.; Cano, M.; Gallego, M.; Camino, S.; Camino, J.A.; Navarrete, B. Evaluation of MEA 5 M performance at different $\mathrm{CO}_{2}$ concentrations of flue gas tested at a $\mathrm{CO}_{2}$ capture lab-scale plant. Energy Procedia 2017, 114, 6222-6228. [CrossRef]

35. Leonzio, G. Upgrading of biogas to bio-methane with chemical absorption process: Simulation and environmental impact. J. Clean. Prod. 2016, 131, 364-375. [CrossRef]

36. Ahn, J.W.; Kim, J.H.; Park, H.S.; Kim, J.A.; Han, C.; Kim, H. Synthesis of single phase aragonite precipitated calcium carbonate in $\mathrm{Ca}(\mathrm{OH})_{2}-\mathrm{Na}_{2} \mathrm{CO}_{3}-\mathrm{NaOH}$ reaction system. Korean J. Chem. Eng. 2005, 22, 852-856. [CrossRef] 
37. Yeh, J.; Pennline, H.; Resnik, K. Study of $\mathrm{CO}_{2}$ absorption and desorption in a packed column. Energy Fuels 2001, 15, 272-278. [CrossRef]

38. Rao, A.B.; Rubin, E.S. A Technical, Economic, and Environmental Assessment of Amine-Based $\mathrm{CO}_{2} \mathrm{Capture}$ Technology for Power Plant Greenhouse Gas Control. Environ. Sci. Technol. 2002, 36, 4467-4475. [CrossRef] [PubMed]

39. Librandi, P.; Costa, G.; De Souza, A.C.B.; Stendardo, S.; Luna, A.S.; Baciocchi, R. Carbonation of Steel Slag: Testing of the Wet Route in a Pilot-scale Reactor. Energy Procedia 2017, 114, 5381-5392. [CrossRef]

40. Morone, M.; Costa, G.; Polettini, A.; Pomi, R.; Baciocchi, R. Valorization of steel slag by a combined carbonation and granulation treatment. Miner. Eng. 2014, 59, 82-90. [CrossRef]

41. Santos, R.M.; Knops, P.C.M.; Rijnsburger, K.L.; Chiang, Y.W. $\mathrm{CO}_{2}$ Energy Reactor-Integrated Mineral Carbonation: Perspectives on Lab-Scale Investigation and Products Valorization. Front. Energy Res. 2016. [CrossRef]

42. Baciocchi, R.; Carnevale, E.; Corti, A.; Costa, G.; Lombardi, L.; Olivieri, T.; Zanchi, L.; Zingaretti, D. Innovative process for biogas upgrading with $\mathrm{CO}_{2}$ storage: Results from pilot plant operation. Biomass Bioenergy 2013, 53, 128-137. [CrossRef]

43. Konno, H.; Nanri, Y.; Kitamura, M. Crystallization of aragonite in the causticizing reaction. Powder Technol. 2002, 123, 33-39. [CrossRef]

44. Dandeu, A.; Humbert, B.; Carteret, C.; Muhr, H.; Plasari, E.; Bossoutrot, J.M. Raman spectroscopy-A powerful tool for the quantitative determination of the composition of polymorph mixtures: Application to $\mathrm{CaCO}_{3}$ polymorph mixtures. Chem. Eng. Technol. 2006, 29, 221-225. [CrossRef]

45. Altiner, M.; Yildirim, M. Production of precipitated calcium carbonate particles with different morphologies from dolomite ore in the presence of various hydroxide additives. Physicochem. Probl. Miner. Process 2017, 53, 413-426. [CrossRef]

(C) 2018 by the authors. Licensee MDPI, Basel, Switzerland. This article is an open access article distributed under the terms and conditions of the Creative Commons Attribution (CC BY) license (http://creativecommons.org/licenses/by/4.0/). 